\title{
購入品目数から見た野菜の購買行動と食意識の特徵
}

\author{
山本 淳子（中央農業総合研究センター） \\ 大浦 裕二（中央農業総合研究センタ一）
}

\section{Characteristics of Consumers' Vegetables Purchasing Behavior and Food Consciousness: Analyzing Purchased Item Numbers}

\author{
Junko Yamamoto (National Agricultural Research Center) \\ Yuji Oura (National Agricultural Research Center)
}

This article clarifies the buying pattern and food consciousness of consumers based on the number of vegetables purchased, by utilizing the consumer monitor records of food purchase and questionnaires.

1. There is a large difference of between 2 to 26 items of vegetables purchased in one week between various monitors. However, there was no difference in the working status, family income, or family composition of the monitors.

\section{1. 課題}

近年, 健康促進の観点から野菜の消費拡大が政策 的に進められている ${ }^{1)}$. しかし，そのような野菜の 消費拡大にあたっては，消費者の野菜の消費実態や その背景にある意識, さらには消費を抑制している 要因を把握しておくことが重要である.

これまでの野菜の消費に関する研究では, 家計調 査年報等の統計データを用いた食料消費パターンの 分析等に打いて，世代別の消費動向や季節性の存在 が明らかにされている（石橋 [1], 時子山 [2]等). しかし, 消費者のライフスタイルが多様化するなか では, 食のあり方や意識も同様に多様化・複雑化し ていることが予想され，そのため，例えば同じ世代 や所得であっても世帯によって野菜の消費実態はか なり異なると考えられる.

このような状沉を踏まえると, 野菜の消費実態の 解明にあたっては, 統計データだけでなく野菜の購 入や利用に関する具体的な行動データを用いた分析 を行らこと，さらにその行動にはどのような意識が 影響しているかについても検討することが必要であ
2. When comparing the larger number (over 10 items per week) of purchase monitors and the lesser number (less then 10 items a week) of monitors, there was no difference in the frequency of purchase or the type of store they purchased the food at.

3. The monitors who purchased a larger number of items were more enthusiastic about cooking, but the monitors who purchased lesser number of items leaned towards the opposite end.

\section{ると考光られる.}

以上の問題意識から, 本稿では, 食品の購入記録 データをもとに野菜の消費実態を明らかにするとと もに, 就業状況等の属性や食に対する意識との関連 を分析し，野菜消費に影響を与える要因について検 討することを課題とする.

ところで, 近年では外食・中食産業の展開により, 様々な形態で野菜を入手し摂取することが可能であ る、しかしながら，実際には現在もなお，家庭内で の調理が食事に抢ける中心的な形態である ${ }^{2}$. その ため本稿では野菜の消費実態を, 家庭内調理の素材 である生鮮野菜を対象に, その購買行動から捉える. また，生鮮野菜の購入が抑制される要因を検討する ために，生鮮野菜を多く購入する消費者とそうでな い消費者との違いを，購入頻度や購入先の選択，属 性，意識にどのような違いがあるかといら観点から 分析する.

な敃，食に対する意識の影響をより明確にするた めに，世代間の比較を行らのではなく，分析対象を 特定のライフステージ (世代) に限定することとした. 


\section{2. 方法}

分析対象として，仕事や家事，子育ての多忙さか ら生鮮野菜の積極的利用が抑制されやすいと考光ら れる中学生のいる世帯を選定した ${ }^{3)}$. そして, 茨城 県 $R$ 市 ${ }^{4}$ の $30 \sim 40$ 代の女性モニター 21 人に対して, 食品の購入記録調査とアンケートによる意識調査を あわせて実施した。

購入記録調査はWeb 上に入力するもので, 食品 の買い物について日時, 店舗名, 購入品目（品目名, 価格, 産地（青果物のみ）, 調理済み・冷凍の区分）, 買い物に行ったシチュエーション等について， 2 週 間記録してもらった．分析対象モニタ一の属性は, 表1の「合計」闌に示寸通りである.

そして，これら記録データをもとに，食品及び生 鮮野菜の買い物をした日数や利用店舗数, 購入品目 数等をモニターごとに整理するとともに, 生鮮野菜 の購入品目数によってモニタ一を分類し，各層にお ける購買行動や食意識について集計を行った. なお, 以下の分析での「野菜」といら表記は「生鮮野菜」 を示すものとする.

また, 生鮮野菜の購入量に関して, 野菜は品目に よって形状や重量, 価格が様々であることから, 本 稿では購入量に代替する指標として「購入品目数」 を用いた。これは，購入した品目の合計数を 1 回の 店舗利用ごとに算出し，それらを合計したものであ る ${ }^{5}$. このため厳密には購入量の分析とはなってい ないが, 野菜の特性を考慮し, 購入した延べ品目数 についての分析を行らこととした。

\section{3. 野菜の購買行動の特徵}

まず図 1 に，週当たりの買い物日数を各モニター について示した．食品全体の買い物日数（野菜を購 入した日数と野菜以外の品目のみを購入した日数の 合計）は，週当たり平均 5.1 日，そのらち野菜を購 入しているのは 3.5 日である. このよらに食品の買 い物頻度は高く，野菜に限っても 2 日に 1 回のペー スであることがわかる，ただし，野菜を購入した日 数は 1.5 日〜 5.5 日，食品全体も 1.5 日〜 7 日とモ ニターによる差が大きい.

次に，何種類の店を利用したか（利用店舗数）と それら店舗を延べ何度利用したか（店舗の延べ利用 回数）を見ていく．週当たりの利用店舗数は，食品 を購入した買い物全体では $1 \sim 7$ 店埔と幅があり平 均は 3.3 店舗（図は省略），野菜を購入した買い物で は $1 \sim 3.5$ 店舗で平均は 1.9 店舗であった（図 2)。ま た，店舗の延べ利用回数（週当たり）は，食品の買 い物全体では平均 6.9 回，そのらち野菜を購入した買 い物は 3.7 回である。ただし，この野菜を購入した買 い物はモニターによって 1.5 回から 6.5 回と幅広い.

さらに，週当たりの総購入品目数は（図 3), 野 菜では平均 10.0 品目であるが, $2 \sim 26$ 品目とモ二 ターによって大きな違いがあった．野菜以外の品目 も含めた食品全体では平均 42.4 品目, $16.5 \sim 82$ 品 目である。

これらのことからは,「多頻度で 1 回に少量を購 入する」といら購買行動の全体的な傾向がわかるが, 同時に，購買頻度や利用店舗数，購入品目数のいず

\section{表 1.モニター属性}

\begin{tabular}{|c|c|c|c|c|c|c|c|c|c|c|c|}
\hline & & \multirow[b]{2}{*}{$\begin{array}{l}モ= \\
\text { ター数 }\end{array}$} & \multicolumn{2}{|c|}{ 年代 } & \multicolumn{2}{|c|}{ 子供の数 } & \multicolumn{2}{|c|}{ 家族構成 } & \multicolumn{3}{|c|}{ ライフステージ } \\
\hline & & & 30 代 & 40 代 & 2 人 & 3 人 & 2 世代 & 3 世代 & $\begin{array}{l}\text { 末子が } \\
\text { 小学生 } \\
\text { 末満 }\end{array}$ & $\begin{array}{l}\text { 末子が } \\
\text { 小学生 }\end{array}$ & $\begin{array}{l}\text { 末子が } \\
\text { 中学生 }\end{array}$ \\
\hline \multicolumn{2}{|c|}{$\begin{array}{c}\text { 合計 } \\
\end{array}$} & 21 & 6 & 15 & 15 & 6 & 16 & 5 & 2 & 17 & 2 \\
\hline \multirow{2}{*}{$\begin{array}{l}\text { 週あたり野菜 } \\
\text { 購入品目数 }\end{array}$} & 10 品目以上 & 11 & 2 & 9 & 8 & 3 & 9 & 2 & 0 & 9 & 2 \\
\hline & 10 品目未満 & 10 & 4 & 6 & 7 & 3 & 7 & 3 & 2 & 8 & 0 \\
\hline & & & & \multicolumn{3}{|c|}{ 就業状況 } & \multicolumn{4}{|c|}{ 世帯年収 } & \\
\hline & & $\begin{array}{l}モ= \\
\text { ター数 }\end{array}$ & 世帯 & $\begin{array}{l}\text { 週40時 } \\
\text { 間以上 }\end{array}$ & $\begin{array}{l}\text { 週40時 } \\
\text { 間未満 }\end{array}$ & 無職 & $\begin{array}{l}700 \text { 万 } \\
\text { 円未満 }\end{array}$ & $\begin{array}{c}700 \sim \\
1000 \text { 万 } \\
\text { 円 }\end{array}$ & $\begin{array}{l}1000 \text { 万 } \\
\text { 円以上 }\end{array}$ & 不明 & \\
\hline \multicolumn{2}{|c|}{ 合計 } & 21 & 4.7 & 6 & 7 & 8 & 6 & 6 & 2 & 7 & \\
\hline \multirow{2}{*}{$\begin{array}{l}\text { 週あたり野菜 } \\
\text { 購入品目数 }\end{array}$} & 10 品目以上 & 11 & 4.5 & 3 & 4 & 4 & 3 & 3 & 1 & 4 & \\
\hline & 10 品目未満 & 10 & 4.8 & 3 & 3 & 4 & 3 & 3 & 1 & 3 & \\
\hline
\end{tabular}




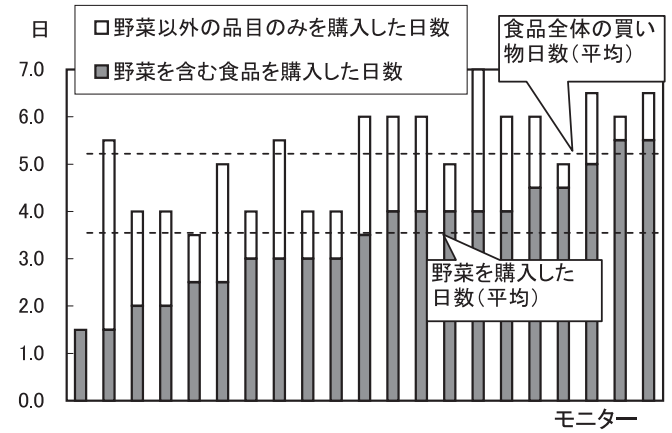

図 1. 買い物日数（週当たり）

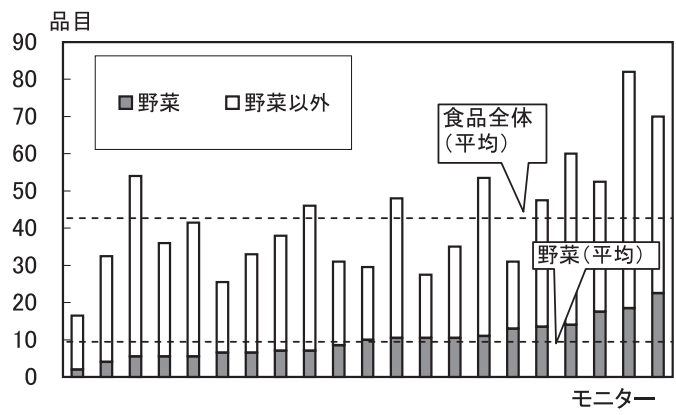

図 3. 総購入品目数（週当たり）

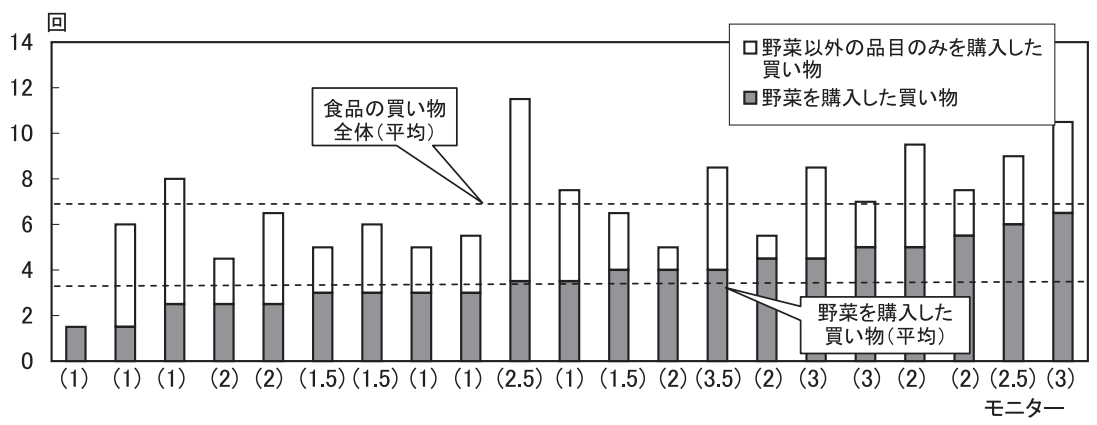

図 2. 店舗の延べ利用回数（週当たり）

注 : 1）グラフは，店舗の延べ利用回数（延べ利用店舗数）を週当たりで示したものである.

2）カッユ内の数字は，野菜の購入に利用した店舗の数（何種類の店を利用したか）を週当たりで示したものである.

れについてもモニターによる違いが大きい. そこで, モ二タ一の就業状況や世帯年収, 家族構成, 末子の 年齢等によるクロス集計を行ったが，これらの属性 による明確な違いは確認できなかった。

次に, 野菜の購入先の特徵として, 表 2 に業態別 の延べ利用回数を示す. 食品の買い物全体では, 食 品スーパーを中心としたスーパーが大部分を占めて 扣り，これに生協等宅配（ただしほとんどが生協） やドラッグストアが加わる. 野菜の購入に利用した 店舗も同様に食品スーパーが中心である.な拈, こ れらの購入先の特徴についても, モニタ一属性によ る明確な違いは見られなかった。

\section{4. 購入品目数から見た野菜の購買行動と食に対す る意識の特徵}

前述したように，消費者によって野菜の購入品目 数が大きく異なることから, 本稿ではこの購入品目 数に注目した分析を行ら. 以下では, モニターを週 当たりの購入品目数が「10 品目以上」とそれに満た
ない「10 品目未満」の 2 階層に分け, 購買行動やモ ニタ一属性，食に対する意識の違いを検討する ${ }^{6}$.

\section{（1）購入品目数別にみた野菜の購入頻度や購入先の 特徵}

まず，表 3 に購入頻度及び購入品目数を示す．週 当たりの買い物をした日数や店舗の延べ利用回数 は, 食品全体では「10 品目以上」層と「10 品目未満」 層はほとんど変わらず，野菜を購入した買い物に限 ると「10品目以上」の方がやや多いが有意差は確 認されなかった。 また，野菜の購入品目数は当然の ことながら「10品目以上」層が多く，それを反映 して野菜以外含めた購入品目数も多くなって掠 り,これは 1 回の店舗利用当たり購入品目数につい ても同様である.

次に, 業態別延べ利用回数については（表 4),「10 品目以上」で「生協等宅配」の利用回数が多いなぞ の特徵があるものの, 全体としては利用する業態に 大きな違いは見ら机ない。

つまり, 野菜の購入品目数が 10 品目以上のモ二 


\section{表 2. 業態別延べ利用回数（週当たり）}

\begin{tabular}{|c|c|c|c|c|c|c|c|}
\hline & $\begin{array}{c}\text { 総合 } \\
\text { スーパー }\end{array}$ & $\begin{array}{l}\text { 食品 } \\
\text { スーパー }\end{array}$ & $\begin{array}{l}\text { ディスカウン } \\
\text { ト系スーパー }\end{array}$ & $\begin{array}{c}\text { ドラッグ } \\
\text { ストア }\end{array}$ & 小売店 & $\begin{array}{l}\text { 生協 } \\
\text { (宅配) }\end{array}$ & その他 \\
\hline 買い物全体 & 0.5 & 4.3 & 0.3 & 0.5 & 0.1 & 0.5 & 0.5 \\
\hline 5ち野菜購入 & 0.4 & 2.9 & 0.1 & 0.0 & 0.1 & 0.3 & 0.0 \\
\hline
\end{tabular}

注：1）その他はコンビニエンスストア，百貨店，会員制卸等である.

2）モニターが調査期間内に食品の購入に利用した店舗は，総合スーパー 3 店舗（市内 2 ，市外 1)，食品スーパー 19 店舗（市内 9 , 市外 10)，ディスカウント系スーパー 4 店舗（市内 1 ，市外 3 ），ドラッグストア 4 店舗（市内 2 ，市 外 2), 小売店 2 店舗（市内 1 , 市外 1), 生協等宅配 6（らち生協 4）であった.

表 3. 野菜の購入品目数別に見た購買行動 (1)（購入頻度, 購入品目数）

\begin{tabular}{|c|c|c|c|c|c|c|c|c|c|}
\hline \multirow{2}{*}{$\begin{array}{c}\text { 週あたり } \\
\text { 野菜購入 } \\
\text { 品目数 }\end{array}$} & \multirow{2}{*}{$モ=タ-$ 数 } & \multicolumn{2}{|c|}{$\begin{array}{c}\text { 買物をした日数 } \\
\text { (週当たり） }\end{array}$} & \multicolumn{2}{|c|}{$\begin{array}{c}\text { 店舗の延べ利用回数 } \\
\text { (週当たり） }\end{array}$} & \multicolumn{2}{|c|}{$\begin{array}{l}\text { 総購入品目数 } \\
\text { （週当たり） }\end{array}$} & \multicolumn{2}{|c|}{$\begin{array}{l}1 \text { 回の店舗利用 } \\
\text { 当たり購入品目数 }\end{array}$} \\
\hline & & 食品全体 & $\begin{array}{l}\text { らち野菜 } \\
\text { 購入 }\end{array}$ & 食品全体 & $\begin{array}{l}\text { らち野菜 } \\
\text { 購入 }\end{array}$ & 食品全体 & らち野菜 & 全品目 & らち野菜 \\
\hline 10 品目以上 & 11 & 5.0 & 3.7 & 6.8 & 4.0 & 48.7 & 13.7 & 8.1 & 3.9 \\
\hline 10 品目未満 & 10 & 5.2 & 3.2 & 7.0 & 3.4 & 35.4 & 5.8 & 5.2 & 1.7 \\
\hline $\begin{array}{c}\text { 計 } \\
\end{array}$ & 21 & 5.1 & 3.5 & 6.9 & 3.7 & 42.4 & 10.0 & 6.7 & 2.9 \\
\hline 有意確率 & - & 0.86 & 0.31 & 0.90 & 0.21 & 0.05 & 0.00 & 0.04 & 0.00 \\
\hline
\end{tabular}

注 : 有意確率は分散分析の結果を示す。網掛けは有意確率が $0.00 \sim 0.1$ 未満である.

表 4. 野菜の購入品目数別に見た購買行動(2)（業態別延べ利用回数）

\begin{tabular}{|c|c|c|c|c|c|c|c|c|c|}
\hline & $\begin{array}{c}\text { 週あたり野菜 } \\
\text { 購入品目数 }\end{array}$ & $\begin{array}{c}モ=\text { タ- } \\
\text { 数 }\end{array}$ & $\begin{array}{c}\text { 総合 } \\
\text { スーパー }\end{array}$ & $\begin{array}{c}\text { 食品 } \\
\text { スーパー }\end{array}$ & $\begin{array}{c}\text { ディスカウント } \\
\text { 系スーパー }\end{array}$ & $\begin{array}{c}\text { ドラッグ } \\
\text { ストア }\end{array}$ & 小売店 & $\begin{array}{l}\text { 生協等 } \\
\text { 宅配 }\end{array}$ & その他 \\
\hline \multirow{3}{*}{$\begin{array}{l}\text { 買い物 } \\
\text { 全体 }\end{array}$} & 10 品目以上 & 11 & 0.4 & 4.2 & 0.3 & 0.7 & 0.1 & 0.8 & 0.2 \\
\hline & 10 品目未満 & 10 & 0.7 & 4.4 & 0.3 & 0.3 & 0.2 & 0.2 & 0.9 \\
\hline & \multicolumn{2}{|c|}{ 有意確率 } & 0.35 & 0.80 & 0.93 & 0.18 & 0.91 & 0.08 & 0.02 \\
\hline \multirow{3}{*}{$\begin{array}{c}5 \text { ち野菜 } \\
\text { 購入 }\end{array}$} & 10 品目以上 & 11 & 0.3 & 3.3 & 0.1 & 0.0 & 0.1 & 0.5 & 0.0 \\
\hline & 10 品目未満 & 10 & 0.5 & 2.8 & 0.1 & 0.0 & 0.1 & 0.1 & 0.1 \\
\hline & \multicolumn{2}{|c|}{ 有意確率 } & 0.45 & 0.31 & 0.71 & - & 0.61 & 0.09 & 0.31 \\
\hline
\end{tabular}

注 : 有意確率は分散分析の結果を示す. 網掛けは有意確率が $0.00 \sim 0.1$ 未満である.

ターと 10 品目末満のモニターでは, 買い物をした 日数や店舗の利用回数, よく利用する業態といった 食品の購買行動自体に明確な違いがあるわけではな い. その中で「10 品目以上」層は野菜の購入品目 数が多く，すなわち野菜を一度に多く購入している ことがわかる。

\section{（2）野菜の購入品目数別に見たモニター属性及び食 意識の特徵}

続いて，各層のモニターの特徵を把握する．表 1 に購入品目数別にモニターの属性を整理したが，年 代，子供の数，家族構成（世代数），末子の年齢， 世帯員数，就業状況及び世帯年収のいずれに関して も，汇とんど違いは見られない。
次に，モニターの食に対する意識を「食関連家事 の負担感」と「食に関する行動・考え方のタイプに ついての自己評価」の 2 つ側面から把握し，野菜 の購入品目数別に整理した.

食関連家事の負担感については（表 5)，各層の 平均值を見ると,「食料品の買い物に行く」と「キッ チン清掃」を除いて，「10 品目未満」の方が負担感 が大きいといら結果になっている.特に,「盛りつけ・ 配膳」では有意差が確認された。

また，食に関する行動・考え万のタイプについて の自己評価を表 6 に示した. ここでは平均値が高い ほどより「あてはまる」ことを示している，店舗選 択（食品の買い物）に関しては，「10 品目未満」層 
表 5. 野菜の購入品目数別に見た家事の負担感

\begin{tabular}{|c|c|c|c|c|c|c|c|c|c|c|c|c|c|}
\hline \multirow[b]{3}{*}{$\begin{array}{c}\text { 週あたり } \\
\text { 野菜購入品目数 }\end{array}$} & \multicolumn{13}{|c|}{ 食関連家事の負担感（5 段階評価） } \\
\hline & \multirow[b]{2}{*}{$\begin{array}{l}\text { 献 } \\
\frac{1}{d} \\
\frac{z}{z} \\
\text { 考 } \\
\text { 学 } \\
\text { る }\end{array}$} & \multirow[b]{2}{*}{$\begin{array}{c}\text { 食 } \\
\text { 物 } \\
\text { に品 } \\
\text { 行 } \\
\text { 今 買 } \\
\text { W }\end{array}$} & \multicolumn{7}{|c|}{ 調理 } & \multicolumn{4}{|c|}{ 片付け等 } \\
\hline & & & 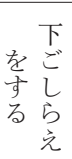 & $\begin{array}{l}\text { 長 } \\
\text { 時 } \\
\text { 間 } \\
\text { 著 } \\
\text { 学 }\end{array}$ & $\begin{array}{l}\text { 炒 } \\
\text { め肉 } \\
\text { る 焼 } \\
\text { る, }\end{array}$ & $\begin{array}{l}\text { 魚 } \\
\text { 奔 } \\
\text { 贲 } \\
\text { く }\end{array}$ & 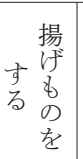 & $\begin{array}{c}\text { 味 } \\
\text { す付 } \\
\text { る 活 } \\
\text { を }\end{array}$ & 配爰 & $\begin{array}{l}\text { 後 } \\
\text { 伤 } \\
\text { 讨 }\end{array}$ & $\begin{array}{c}\text { 生 } \\
\text { 始 } \\
\text { 末 } \\
\text { の }\end{array}$ & $\begin{array}{l}\text { ב゙ } \\
\text { ミ } \\
\text { 分 } \\
\text { 別 }\end{array}$ & $\begin{array}{c} \\
\text { 清 } \\
\text { 掃 } \\
\text { チ } \\
\text { ン }\end{array}$ \\
\hline$\lceil 10$ 品目以上 $\rfloor$ 平均值 $(\mathrm{A})$ & 3.7 & 3.5 & 2.5 & 2.0 & 1.6 & 1.5 & 2.5 & 1.9 & 1.8 & 3.7 & 3.1 & 2.2 & 3.4 \\
\hline 「10 品目未満」平均值 $(\mathrm{B})$ & 4.1 & 3.0 & 3.4 & 2.3 & 2.0 & 2.4 & 3.0 & 2.1 & 2.4 & 4.3 & 3.5 & 3.1 & 3.3 \\
\hline$(\mathrm{A})-(\mathrm{B})$ & -0.4 & 0.5 & -0.9 & -0.3 & -0.4 & -0.9 & -0.5 & -0.2 & -0.6 & -0.6 & -0.4 & -0.9 & 0.1 \\
\hline 有意確率 & 0.45 & 0.39 & 0.12 & 0.44 & 0.17 & 0.44 & 0.44 & 0.59 & 0.08 & 0.28 & 0.43 & 0.07 & 0.91 \\
\hline
\end{tabular}

注：1）「負担に思わない」1〜「負担に思う」5 までの 5 段階評価の平均值である.

2）有意確率は分散分析の結果を示す。網掛忛有意確率が $0.00 \sim 0.1$ 未満である.

表 6. 野菜の購入品目数別に見た普段の行動と食に関する意識の自己評価

\begin{tabular}{|c|c|c|c|c|c|}
\hline \multirow[b]{2}{*}{$\begin{array}{c}\text { 週当たり } \\
\text { 野菜購入品目数 }\end{array}$} & \multicolumn{5}{|c|}{ 店舗選択（買い物）に関する事項 } \\
\hline & $\begin{array}{l}\text { 食料品の買い物が } \\
\text { 好き }\end{array}$ & \begin{tabular}{|l|}
$\mid$ 新しい食料品店が \\
できたらすぐに \\
行ってみたい方だ
\end{tabular} & $\begin{array}{l}\text { 食料品の買物にあ } \\
\text { まり時間をかけな } \\
\text { い方だ }\end{array}$ & \begin{tabular}{|l|} 
価格の安い食料品 \\
店を利用する方だ
\end{tabular} & - \\
\hline$\lceil 10$ 品目以上」平均值 (A) & 3.5 & 2.3 & 3.3 & 3.9 & - \\
\hline 「10 品目未満」平均值（B） & 3.7 & 3.3 & 3.4 & 4.2 & - \\
\hline$(\mathrm{A})-(\mathrm{B})$ & -0.2 & -1.1 & -0.2 & -0.3 & - \\
\hline 有意確率 & 0.75 & 0.06 & 0.80 & 0.36 & - \\
\hline \multirow[b]{2}{*}{$\begin{array}{c}\text { 週当たり } \\
\text { 野菜購入品目数 }\end{array}$} & \multicolumn{5}{|c|}{ 商品選択に関する事項 } \\
\hline & $\begin{array}{l}\text { 同じ食品の銘柄 } \\
\text { (ブランド) をよ } \\
\text { く利用する方だ }\end{array}$ & \begin{tabular}{|l|} 
地場産の農産物を \\
利用する方だ
\end{tabular} & $\begin{array}{l}\text { 農薬や抗生物質の } \\
\text { 使用が気になる }\end{array}$ & \begin{tabular}{|l|} 
下ごしらえ済みの \\
食材を利用する方 \\
だ
\end{tabular} & $\begin{array}{l}\text { 食品表示をよく読 } \\
\text { む方だ }\end{array}$ \\
\hline$\lceil 10$ 品目以上」平均值 $(\mathrm{A})$ & 3.9 & 3.5 & 4.1 & 2.0 & 4.4 \\
\hline 「10 品目未満」平均値 (B) & 3.2 & 2.9 & 3.6 & 2.5 & 3.3 \\
\hline$(\mathrm{A})-(\mathrm{B})$ & 0.7 & 0.6 & 0.5 & -0.5 & 1.1 \\
\hline 有意確率 & 0.27 & 0.24 & 0.35 & 0.34 & 0.00 \\
\hline \multirow[b]{2}{*}{$\begin{array}{c}\text { 週当たり } \\
\text { 野菜購入品目数 }\end{array}$} & \multicolumn{5}{|c|}{ 調理・保存に関する事項 } \\
\hline & $\begin{array}{l}\text { 料理を作ることが } \\
\text { 好き }\end{array}$ & \begin{tabular}{|l|} 
料理のレパート \\
リーは多い方だ
\end{tabular} & $\begin{array}{l}\text { 食器の盛りつけに } \\
\text { は気を使ら方だ }\end{array}$ & \begin{tabular}{|}
$\mid$ 健康に気をつけた \\
買い物や食事を心 \\
掛けている
\end{tabular} & $\begin{array}{l}\text { 保存していた食品 } \\
\text { が駄目になり捨て } \\
\text { ることが多い方だ }\end{array}$ \\
\hline$\lceil 10$ 品目以上」平均值 $(\mathrm{A})$ & 3.5 & 3.4 & 3.6 & 4.4 & 2.4 \\
\hline 「10 品目未満」平均値 (B) & 2.8 & 2.6 & 2.9 & 3.3 & 3.1 \\
\hline$(\mathrm{A})-(\mathrm{B})$ & 0.7 & 0.8 & 0.7 & 1.1 & -0.7 \\
\hline 有意確率 & 0.20 & 0.08 & 0.13 & 0.01 & 0.18 \\
\hline
\end{tabular}

注：1）「あてはまらない」1〜「あてはまる」5までの 5 段階評価の平均值である.

2）有意確率は分散分析の結果を示す．網掛けは有意確率が $0.00 \sim 0.1$ 未満である.

で「新しい食料品店ができたらすぐに行ってみたい」 傾向があるが，その他の項目では大きな違いは見ら れなかった。

商品選択に関わる項目では，「10 品目以上」の方 が「同じ食品のブランドをよく利用する方だ」「地 場農の農産物を利用する方だ」「農薬や抗生物質の
使用が気になる万だ」「食品法事をよく読む方だ」 の各項目の平均值が高く，このうち「食品表示をよ く読む」については有意差があった.

調理・保存に関する項目では,「10 品目以上」の 方が,「料理を作ることが好き」「料理のレパートリー は多い方だ」「食器の盛りつけには気を使ら方だ」健 
康に気をつけた買い物や食事を心がけている」の項 目で平均值が高く，「料理のレパートリーは多い方 だ」「健康に気をつけた買い物や食事を心がけてい る」では有意差が確認された。 また，「保存してい た食品がだめになり捨てることが多い」については, $\lceil 10$ 品目未満」の方が平均值が高くなっている.

これらのことからは，「10 品目以上」層は，相対 的に健康志向が強く, レパートリーを多く持つなど 調理に対して積極的な姿勢がうかがえる. 一方, 「10 品目未満」層は, 買い物への関心はあるものの調理 や片づけの負担感が相対的に高い傾向が見られる.

\section{5. 考察}

本稿では, 記録データから消費者の生鮮野菜の購 買行動の実態を把握するとともに，生鮮野菜を多く 購入する消費者とそらでない消費者との購買行動及 び食に対する意識の比較を行った. その結果, 食品 の購買頻度や購入先の選択といった行動には明確な 違いは見られないこと, その中で生鮮野菜を多く購 入する消費者は 1 回の買い物で購入品目数が多いこ とが明らかになった。

また, 食に対する意識については, 生鮮野菜の購 入が少ない消費者は，買い物は好きだが下ごしらえ 等の調理や片付けの負担感が相対的に高い傾向にあ ること, 一方で生鮮野菜の購入が多い消費者は, 調 理への積極的な姿勢がより強いといった傾向にある ことがわかった.

これらの結果は, 生鮮野菜の購入に対しては, 食 品の購入頻度や購入先の選択といった購買行動より も食に対する意識の方が影響していること, さらに この食意識に関しても, 買い物に行くといら行為に 対する意識よりも, 調理・保存に関わる意識の方が より影響していることを示唆している. これは, 野 菜の多くの品目で洗ら・切るといった下ごしらえや 加熱等の調理が必要であること, さらに食事のメ ニューには複数の野菜を組み合わせたものが多いこ とから, 調理場面の意識のあり方が購入品目数に影 響し，その結果，調理が相対的に好きでなかったり 手間であると考えている消費者において, 生鮮野菜 の購入が抑制される傾向にあると考えられる.

な抏，本稿の分析は少数のモ二タ一の事例調査に 基づくものであることから，今後は，より多くのモ ニターによる検証や他のライフステージを対象とし
た分析を行っていく必要がある。また，本稿では生 鮮野菜の購入量に限定したが，中食や外食に颃ける 野菜摂取の実態把握や，それらと生鮮野菜の購入量 との関連についても今後分析していく必要がある.

注 1）農林水産省と厚生労働省による「食事バランスガ イド」の取り組みや, ファイブ・ア・デイ協会に よる「ファイブ・ア・デイ」運動などがある.

2）総務省家計調査年報（平成 19 年）によると，食料 支出に占める調理食品費及び外食費の割合は $33 \%$ であり，購入頻度で見ると $12 \%$ にどまっている．

3）生鮮野菜の積極的利用が抑制されやすいと考光ら れるライフステージを分析対象としたのは，その 中でもな打積極的利用をする消費者とそらでない 消費者とを比較することで，行動や意識の違いが より明確になると考えたからである。また，一般 に子供が中学生ぐらいの年代になると仕事を再開 している主婦が多く，同時に近年では子供の習い 事等の送り迎えが頻繁であるなど無職であっても 時間的余裕のない主婦が多いと考えられる．この ような時間的制約が生鮮野菜の積極的利用に影響 すると考え, 中学生のいる世帯を分析対象とした.

4） R市は茨城県南部に所在し, 東京への通勤圏にある. 市街地 2 地区と新興住宅地 2 地区から成り, 各地 区にスーパー等の小売店舗が複数存在している.

5）例えば，ある店でトマト 3 個とキャベッ 1 玉を購 入した場合はトマトとキャベッの 2 品目とし，別 の日にトマトとキャベッを購入すると, 再度これ ら 2 品目をカウントしている.な技，同日に別の 店で同じ品目を購入した場合には 1 品目とした(た だし,これに該当するデータは 1 件のみであった).

6) モニター 21 人の生鮮野菜の 1 週間当たり購入品目 数は, 図 3 のように分布に大きな偏りがなく, 平 均值 10.0 品目, 中央值 10.0 品目であったことから, これらの点を考慮して「10品目以上」と「10品目 未満」の 2 グループに分けることにした。なお, グループ間の比較にあたっては，購入品目数が特 に多い層と特に少ない層等を抽出する方法も考兄 られるが，モニター数が必ずしも十分ではないこ とから本稿では 2 グループ間の分析に留めた.

\section{参考文献}

[1] 石橋喜美子「年齢階級別消費量の推計一家計 調査個票データを使用して一」, 森宏編『食料 消費のコウホート分析一年齢・世代・時代一』, 専修大学出版局, 2001 年, pp. 187-228.

［2］時子山ひろみ『フードシステムの経済分析』, 日本評論社, 1999 年. 